\title{
Granulocyte Colony Stimulating Factor in the Treatment of Cardiac Ischemic Disease. A Decade has Passed: Is it Time to Give Up?
}

\author{
Editorial to "Disassociation between Left Ventricular Mechanical and Electrical \\ Properties in Ischemic Rat Heart after G-CSF Treatment" by Liu et al.
}

\author{
Ruy Andrade N. Louzada • \\ João Pedro Saar Werneck-de-Castro
}

Published online: 1 June 2011

(C) Springer Science+Business Media, LLC 2011

Therapies with stem cells have been proposed as a solution for decreased systolic capacity after cardiomyocyte death and/or to prevent cell death after an ischemic event. New host cell formation, activation of tissue progenitor cells, secretion of angiogenic and/or survival signals are some of the mechanisms that may explain the benefits of cell transplantation. Cell administration has been done by either intramyocardial or intracoronary route, implying that patients or animals are subject to surgery or to invasive hemodynamic procedure. The possibility of using growth factors capable of mobilizing stem cells to the circulation and induce their homing to the infarcted heart has therefore great therapeutic appeal since it would avoid invasive procedures. Granulocyte-colony stimulating factor (G-CSF) appears to be the major potential candidate because it has been used for many decades in patients with hematopoietic disorders without any serious adverse side effects and is known to mobilize hematopoietic [1], endothelial [2] and mesenchymal [3] precursor cells from bone marrow.

In the present issue of Cardiovascular Drugs and Therapy Liu et al point out a distinct effect of G-CSF after

R. A. N. Louzada $\cdot$ J. P. S. Werneck-de-Castro $(\bowtie)$

Departamento de Biociências e Atividade Física, CCS,

Escola de Educação Física e Desportos, Ilha do Fundão,

Universidade Federal do Rio de Janeiro (UFRJ),

Carlos Chagas Filho av, 540,

21941-599, Rio de Janeiro, RJ, Brazil

e-mail: joaopedrowerneck@yahoo.com.br

R. A. N. Louzada - J. P. S. Werneck-de-Castro Instituto de Biofísica Carlos Chagas Filho, UFRJ,

Rio de Janeiro CEP 21941-902, Brazil myocardial infarction (MI): a disassociation between left ventricular mechanical and electrical properties in ischemic rat heart after G-CSF treatment [4]. For this purpose, the authors treated ischemic rats with subcutaneous G-CSF injections $(100 \mu \mathrm{g} / \mathrm{kg} / \mathrm{d}$ for five consecutive days) $1 \mathrm{~h}$ or $24 \mathrm{~h}$ after infarction. The main finding was that administration of G-CSF regardless of time of injection had no beneficial effects on cardiac function after cardiac ischemia. Nevertheless, G-CSF treatment was associated with improved electrophysiological properties, decreasing the number of arrhythmic events.

G-CSF research in the field of ischemic heart disease is celebrating 10 years of pre-clinical and clinical work attempting to find a new therapeutic approach for this epidemic worldwide disease. In 2001, Orlic and coworkers, following their previous work using bone marrow lin- c-kit + cells for MI treatment [5], tested G-CSF in combination with Stem Cell Factor (SCF) in a model of acute MI in mice [6]. They found a significant decrease in mortality rate, and increased cardiac function. However the approach used could not be translated to the clinic, since the therapy was started 5 days before MI induction, besides including the use of SCF. Many reports followed the original work of Orlic et al. (2001) due its promising results, increasing the number of G-CSF and MI publications exponentially until 2006 (Fig. 1a). In a simple search at the National Library of Medicine of the National Institutes of Health (http://www.ncbi.nlm.nih.gov/pubmed) combining G-CSF and MI key words present in the title and/or the abstract we found 268 papers between 2000, January first, and 2011, May fifth. In a further delimitation, 
a)

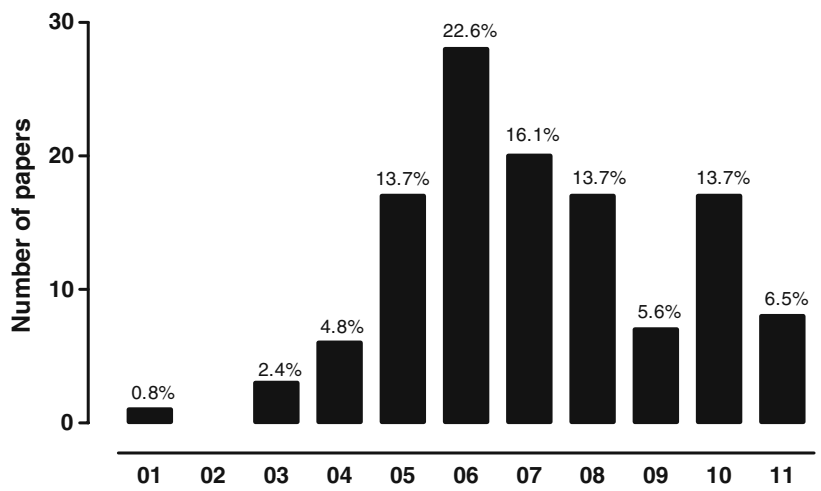

b)

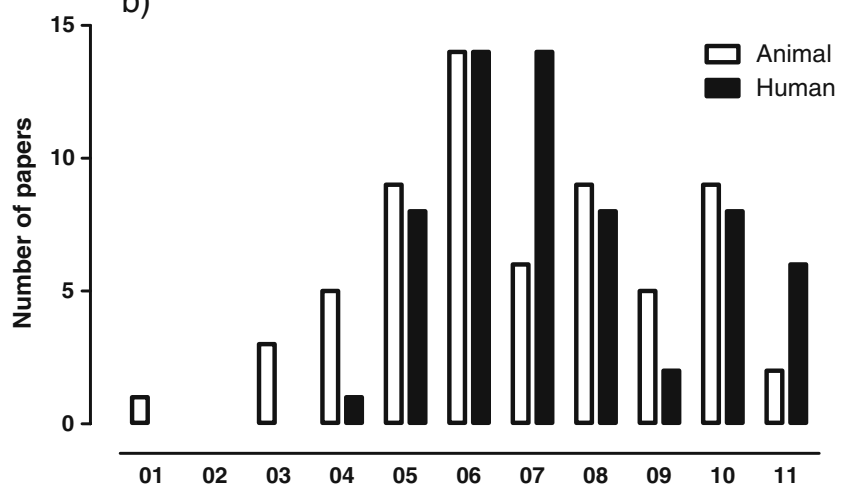

Fig. 1 Number of papers presented by the National Library of Medicine of the National Institutes of Health (http://www.ncbi.nlm. nih.gov/pubmed). a Number of papers published involving C-CSF treatment of myocardial infarction in the last decade (2001-2011). Graph bars represent absolute number of papers and numbers above bars are the percentage of total manuscript $(100 \%=124)$. b Numbers of papers discriminated by humans and animals

we included original studies that tried to treat MI (acute and chronic phases) with G-CSF alone or in combination with other growth factor or cells, and meta-analysis. Additionally we excluded reviews, editorials and comments. At the end of these delimitations 124 manuscripts were selected in the last 10 years. As shown in Fig. 1a, the number of manuscripts involving G-CSF therapy peaked in 2006 accounting for $22 \%$ (28 publications) of the total (124) and then started to fall. Not surprisingly, this drop occurred after negative results were reported both in animals and humans (see discussion below). As expected, clinical trials began to increase 3 years after pre-clinical investigations and peaked in 2006 and 2007 (Fig. 1b).

\section{Pre-clinical experiments}

Mechanical properties - cardiac function and architecture

Two years after Orlic's report, Norol et al (2003) mobilized CD34 cells in baboons, but this was insuffi- cient to increase left ventricle ejection fraction (LVEF) [7]. Although few animals were treated, this was the first work to show the inefficacy of G-CSF treatment. However, in 2004, two important reports strengthened Orlic's findings in rats [8] and rabbits [9]. Ohtshuca et al showed that post-MI treatment with G-CSF alone (without addition of SCF) in non-splenectomized mice had the same effects as Orlic's original protocol [8]. On the other hand, Deten and co-workers using exactly the same protocol and the same species (mice) as Orlic found no functional benefits [10]. Furthermore, they injected G-CSF and SCF $6 \mathrm{~h}$ after MI and, in another group of infarcted mice, administered bone marrow lin- $(31 \%$ of c-kit +$)$ cells into the mice tail vein. These authors reported that even though c-kit + increased from 0.05 to $2.8 \%$ in peripheral blood, growth factor treated mice did not improve their cardiac function performance, or decreased MI size or any sign of cardiac regeneration as well as cell therapy. Until that time, the mechanism of G-CSF action was discussed exclusively by increasing cell mobilization and homing to ischemic heart with conflicting results $[6,8,10-13]$.

Given that and the controversy about the differentiation of HSC into cardiomyocytes [14, 15], a number of studies have focused on a possible direct action of G-CSF on cardiomyocytes [9, 16-18]. Harada et al. [16] demonstrated that cultures of rat and mouse cardiac myocytes and fibroblasts express G-CSF receptor (GCSFR) and that its expression increased after MI. They further showed that G-CSF therapy prevents LV remodeling and improved cardiac function after MI by activating the Jak-Stat signaling pathway. Another local effect of GCSF is the acceleration of the healing process by collagen deposition and scar formation preventing early ventricular expansion after MI [9, 17]. This profibrotic blueprint improved cardiac systolic function. These results are in contrast with a more recent report showing that G-CSF decreased matrix metalloproteinase and increased its inhibitors leading to a huge fibrosis and large infarct sizes in treated rats [19]. Consequently, G-CSF administration caused a progressive dysfunction by ECHO analysis and impairment of the left ventricle to develop pressure. The present study by Liu et al. also demonstrates that early G-CSF treatment $(1 \mathrm{~h}$ post-MI) may exacerbate structural and mechanical deficits post-MI since hemodynamic parameters were depressed and the ventricular expansion index was augmented. In this scenario, our laboratory failed to demonstrate any beneficial effect of G-CSF either in the acute [20] or during the chronic phase of MI [21]. Considering the number of publications, it seems that the interest in this field of research has declined after a series of negative results in pre-clinical studies until 2006 (Fig. 1a and b). 


\section{Clinical trials}

As stated above, G-CSF constitutes an interesting, less invasive stem cell-based strategy to treat heart ischemic disease. Encouraged by pre-clinical data, the first clinical trials to evaluate the feasibility and safety of G-CSF appeared in 2004/2005. G-CSF was utilized to mobilize stem cells and/or treat patients after percutaneous coronary intervention (PCI) [22-24] and confirmed that this new type of treatment could be tested with a minimum of security, although some adverse effects were proposed [25]. After that the number of clinical trials increased two fold in 2006 and 2007, before starting to decrease like the studies in animals (Fig. 1b). Initially, as requested, clinical investigations were performed with a limited number of patients, with or without a placebo group and in an openlabel or single-blind design [22-27]. All confirmed the safety and feasibility of G-CSF treatment. However, a lot of conflicting results were reported about improvement in cardiac function. In 2006, three prospective, randomized, double-blinded, placebo-controlled trials in patients diagnosed with ST-segment elevation acute MI who had successful reperfusion by PCI were performed [28-30]. They used the same dose of G-CSF $(10 \mu \mathrm{g} / \mathrm{kg}$ of body weight) for 5 or 6 consecutive days. Primary or secondary end-points included cardiac function assessed by MRI, and the follow up varied from 3 to 6 months. All studies failed to show benefits of G-CSF treatment in LVEF either when PCI was done early $(<12 \mathrm{hs})[29,30]$ or late (mean of $31 \mathrm{hs}-$ 2 to 107hs) [28]. At the end of 1 year of follow up G-CSF was still inefficacious in improving cardiac function [31]. Furthermore, Engelmann et al confirmed in a small study that timing of G-CSF would not influence myocardial recovery [32]. The largest number of patients (144) enrolled was by Zohlnhöfer et al (2006) [29]. Thus, in an attempt to increase the number of patients some meta-analyses were performed to analyze all data of small trials together [3335]. Zohlnhöfer et al (2008) used 445 patients from randomized, controlled and single or double-blinded studies [34]. Still, from these there was no support for the treatment of those patients with acute MI with G-CSF.

Is it time to give up? To answer this question it would be necessary to carefully perform a phase III prospective, randomized, double-blinded, placebo-controlled and multicenter clinical trial to improve our understanding. However, an unequivocal sign of giving up G-CSF as a monotherapy agent is the search for a partner to be administered mutually. Despite the combination with SCF or GM-CSF, Dawn et al (2006) were the first to combine G-CSF with Flt-3 ligand in MI mice. As postulated by them, G-CSF alone did not improve cardiac function, in contrast to the combined therapy. This was the first study within the first 6 years of the previous decade. In the last 4 years G-CSF has been associated to hepatocyte-growth factor [36], Flt-3 ligand [37], Fas, an antiapoptotic agent [38], parathyroid hormone [39] and erythropoietin [40-43] in animal models and even in humans [44]

\section{Electrophysiological properties}

The onset of MI leads to tissue loss and pump function impairment. Besides, there is an enhanced vulnerability to ventricular arrhythmias, especially within the few hours after reperfusion. One of the concerns about cell therapy is to avoid cardiac electrophysiological adverse effects, since the intramyocardial and intracoronary routes are used for cell delivery and cells can not integrate to host tissue, as described for myoblast transplantation (Menasche et al 2003). The impact of G-CSF treatment after the acute and chronic phases of MI on cardiac electrophysiological properties has been poorly studied compared to the great number of data regarding cardiac mechanical function.

The reduced expression of connexin 43 ( $\mathrm{Cx} 43)$ in the heart after MI is associated with disturbances in electrical conductivity, a decrease in electrical coupling and a higher incidence of arrhythmias [45]. Moreover, myocardial remodeling causes sympathetic hyperinnervation and consequently arrhythmic events [46]. Liu and co-workers [4] present data that indicate that G-CSF-treated hearts had improved electrophysiological outcomes and less inducible ventricular arrhythmias during programmed ventricular stimulation, although the mechanism remains unclear and needs further investigation. Possible mechanisms are through increasing $\mathrm{Cx} 43$ expression as shown by Kuhlmann et al (2006) [47] and Baldo (2008) [48], or stabilization of the $\mathrm{Cx} 43$ protein via Wnt signaling cascade [49]. However, G-CSF injections started before MI and/or were combined with SCF which is clinically irrelevant. Importantly, even though Kuhlmann et al (2006) demonstrated reduced inducibility of ventricular arrhythmias in mice treated 3 days before plus 3 days after MI, they were unable to show an increase in fractional shortening by echocardiography assessment. Thus, their data strengthens the disassociation between left ventricular mechanical and electrical properties. Hence, further studies focusing on electrophysiological properties should investigate the effects of G-CSF treatment after MI and assess ion channels function, connexins expression and myocyte coupling. On the other hand, Lee, MT et al (2009) showed an increase in sympathetic reinnervation after 56 days of MI and, consequently, an increase in arrhythmia incidence [50]. We cannot exclude the possible negative effect of a large fibrotic tissue production reported by others [19] after GCSF injections since scar tissue could reduce the conduction of electrical impulse and promote the re-entry of 
arrhythmic events. In clinical trials, although there are few reports of adverse effects like incidence of re-stenosis and coronary neointima growth [25], phase I/II studies with GCSF administration after MI and percutaneous coronary intervention (reperfusion) demonstrated that this approach is feasible and safe. Furthermore, G-CSF neither enhanced nor diminished ventricular arrhythmia.

Acknowledgements We would like to thank professors Antonio Carlos Campos-de-Carvalho and Doris Rosenthal for reviewing the English.

\section{References}

1. Lapidot T, Petit I. Current understanding of stem cell mobilization: the roles of chemokines, proteolytic enzymes, adhesion molecules, cytokines, and stromal cells. Exp Hematol. 2002;30:973-81.

2. Honold J, Lehmann R, Heeschen C, Walter DH, Assmus B, Sasaki K, et al. Effects of granulocyte colony simulating factor on functional activities of endothelial progenitor cells in patients with chronic ischemic heart disease. Arterioscler Thromb Vasc Biol. 2006;26:2238-43.

3. Tatsumi K, Otani H, Sato D, Enoki C, Iwasaka T, Imamura H, et al. Granulocyte-colony stimulating factor increases donor mesenchymal stem cells in bone marrow and their mobilization into peripheral circulation but does not repair dystrophic heart after bone marrow transplantation. Circ J. 2008;72:1351-8.

4. Liu HM, Luo T, Zhou X, Cai L, Huang TG, Jiang TM, et al. Disassociation between left ventricular mechanical and electrical properties in ischemic rat heart after G-CSF treatment. Cardiovasc Drugs Ther 2011;25:this issue.

5. Orlic D, Kajstura J, Chimenti S, Bodine DM, Leri A, Anversa P. Transplanted adult bone marrow cells repair myocardial infarcts in mice. Ann N Y Acad Sci. 2001;938:221-9. discussion 229-230.

6. Orlic D, Kajstura J, Chimenti S, Limana F, Jakoniuk I, Quaini F, et al. Mobilized bone marrow cells repair the infarcted heart, improving function and survival. Proc Natl Acad Sci U S A. 2001;98:10344-9.

7. Norol F, Merlet P, Isnard R, Sebillon P, Bonnet N, Cailliot C, et al. Influence of mobilized stem cells on myocardial infarct repair in a nonhuman primate model. Blood. 2003;102:4361-8.

8. Ohtsuka M, Takano H, Zou Y, Toko H, Akazawa H, Qin Y, et al. Cytokine therapy prevents left ventricular remodeling and dysfunction after myocardial infarction through neovascularization. FASEB J. 2004;18:851-3.

9. Minatoguchi S, Takemura G, Chen XH, Wang N, Uno Y, Koda M, et al. Acceleration of the healing process and myocardial regeneration may be important as a mechanism of improvement of cardiac function and remodeling by postinfarction granulocyte colony-stimulating factor treatment. Circulation. 2004;109:257280 .

10. Deten A, Volz HC, Clamors S, Leiblein S, Briest W, Marx G, et al. Hematopoietic stem cells do not repair the infarcted mouse heart. Cardiovasc Res. 2005;65:52-63.

11. Brunner S, Huber BC, Fischer R, Groebner M, Hacker M, David $\mathrm{R}$, et al. G-CSF treatment after myocardial infarction: impact on bone marrow-derived vs cardiac progenitor cells. Exp Hematol. 2008;36:695-702.

12. Misao Y, Takemura G, Arai M, Ohno T, Onogi H, Takahashi T, et al. Importance of recruitment of bone marrow-derived CXCR4+ cells in post-infarct cardiac repair mediated by G-CSF. Cardiovasc Res. 2006;71:455-65.

13. Adachi Y, Imagawa J, Suzuki Y, Yogo K, Fukazawa M, Kuromaru $\mathrm{O}$, et al. G-CSF treatment increases side population cell infiltration after myocardial infarction in mice. J Mol Cell Cardiol. 2004;36:707-10.

14. Murry CE, Soonpaa MH, Reinecke H, Nakajima H, Nakajima HO, Rubart M, et al. Haematopoietic stem cells do not transdifferentiate into cardiac myocytes in myocardial infarcts. Nature. 2004;428:664-8.

15. Nygren JM, Jovinge S, Breitbach M, Sawen P, Roll W, Hescheler $\mathrm{J}$, et al. Bone marrow-derived hematopoietic cells generate cardiomyocytes at a low frequency through cell fusion, but not transdifferentiation. Nat Med. 2004;10:494-501.

16. Harada M, Qin Y, Takano H, Minamino T, Zou Y, Toko H, et al. G-CSF prevents cardiac remodeling after myocardial infarction by activating the Jak-Stat pathway in cardiomyocytes. Nat Med. 2005;11:305-11.

17. Sugano Y, Anzai T, Yoshikawa T, Maekawa Y, Kohno T, Mahara $\mathrm{K}$, et al. Granulocyte colony-stimulating factor attenuates early ventricular expansion after experimental myocardial infarction. Cardiovasc Res. 2005;65:446-56.

18. Okada H, Takemura G, Li Y, Ohno T, Li L, Maruyama R, et al. Effect of a long-term treatment with a low-dose granulocyte colony-stimulating factor on post-infarction process in the heart. J Cell Mol Med. 2008;12:1272-83.

19. Cheng Z, Ou L, Liu Y, Liu X, Li F, Sun B, et al. Granulocyte colony-stimulating factor exacerbates cardiac fibrosis after myocardial infarction in a rat model of permanent occlusion. Cardiovasc Res. 2008;80:425-34.

20. Werneck-de-Castro JP, Costa ESRH, de Oliveira PF, PinhoRibeiro V, Mello DB, Pecanha R, et al. G-CSF does not improve systolic function in a rat model of acute myocardial infarction. Basic Res Cardiol. 2006;101:494-501.

21. Louzada RA, Oliveira PF, Cavalcanti-de-Albuquerque JP, CunhaCarvalho L, Baldanza MR, Kasai-Brunswick TH, et al. Granulocyte-colony stimulating factor treatment of chronic myocardial infarction. Cardiovasc Drugs Ther. 2010;24:121-30.

22. Kuethe F, Figulla HR, Herzau M, Voth M, Fritzenwanger M, Opfermann T, et al. Treatment with granulocyte colonystimulating factor for mobilization of bone marrow cells in patients with acute myocardial infarction. Am Heart J. 2005; $150: 115$.

23. Kang HJ, Kim HS, Zhang SY, Park KW, Cho HJ, Koo BK, et al. Effects of intracoronary infusion of peripheral blood stem-cells mobilised with granulocyte-colony stimulating factor on left ventricular systolic function and restenosis after coronary stenting in myocardial infarction: the MAGIC cell randomised clinical trial. Lancet. 2004;363:751-6.

24. Ince H, Petzsch M, Kleine HD, Eckard H, Rehders T, Burska D, et al. Prevention of left ventricular remodeling with granulocyte colony-stimulating factor after acute myocardial infarction: final 1-year results of the Front-Integrated Revascularization and Stem Cell Liberation in Evolving Acute Myocardial Infarction by Granulocyte Colony-Stimulating Factor (FIRSTLINE-AMI) Trial. Circulation. 2005;112:I73-80.

25. Hill JM, Syed MA, Arai AE, Powell TM, Paul JD, Zalos G, et al. Outcomes and risks of granulocyte colony-stimulating factor in patients with coronary artery disease. J Am Coll Cardiol. 2005;46:1643-8.

26. Takano H, Hasegawa H, Kuwabara Y, Nakayama T, Matsuno K, Miyazaki Y, et al. Feasibility and safety of granulocyte colonystimulating factor treatment in patients with acute myocardial infarction. Int J Cardiol. 2007;122:41-7.

27. Valgimigli M, Rigolin GM, Cittanti C, Malagutti P, Curello S, Percoco G, et al. Use of granulocyte-colony stimulating factor 
during acute myocardial infarction to enhance bone marrow stem cell mobilization in humans: clinical and angiographic safety profile. Eur Heart J. 2005;26:1838-45.

28. Engelmann MG, Theiss HD, Hennig-Theiss C, Huber A, Wintersperger BJ, Werle-Ruedinger AE, et al. Autologous bone marrow stem cell mobilization induced by granulocyte colonystimulating factor after subacute ST-segment elevation myocardial infarction undergoing late revascularization: final results from the G-CSF-STEMI (Granulocyte Colony-Stimulating Factor ST-Segment Elevation Myocardial Infarction) trial. J Am Coll Cardiol. 2006;48:1712-21.

29. Zohlnhofer D, Ott I, Mehilli J, Schomig K, Michalk F, Ibrahim T, et al. Stem cell mobilization by granulocyte colony-stimulating factor in patients with acute myocardial infarction: a randomized controlled trial. JAMA. 2006;295:1003-10.

30. Ripa RS, Jorgensen E, Wang Y, Thune JJ, Nilsson JC, Sondergaard L, et al. Stem cell mobilization induced by subcutaneous granulocyte-colony stimulating factor to improve cardiac regeneration after acute ST-elevation myocardial infarction: result of the double-blind, randomized, placebo-controlled stem cells in myocardial infarction (STEMMI) trial. Circulation. 2006;113:1983-92.

31. Engelmann MG, Theiss HD, Theiss C, Henschel V, Huber A, Wintersperger BJ, et al. G-CSF in patients suffering from late revascularised ST elevation myocardial infarction: final 1-yearresults of the G-CSF-STEMI Trial. Int J Cardiol. 2010;144:399404.

32. Engelmann MG, Theiss HD, Theiss C, Huber A, Wintersperger $\mathrm{BJ}$, Werle-Ruedinger AE, et al. G-CSF in patients suffering from late revascularized ST elevation myocardial infarction: analysis on the timing of G-CSF administration. Exp Hematol. 2008;36:7039.

33. Abdel-Latif A, Bolli R, Zuba-Surma EK, Tleyjeh IM, Hornung CA, Dawn B. Granulocyte colony-stimulating factor therapy for cardiac repair after acute myocardial infarction: a systematic review and meta-analysis of randomized controlled trials. Am Heart J. 2008;156:216-26. e219.

34. Zohlnhofer D, Dibra A, Koppara T, de Waha A, Ripa RS, Kastrup $\mathrm{J}$, et al. Stem cell mobilization by granulocyte colony-stimulating factor for myocardial recovery after acute myocardial infarction: a meta-analysis. J Am Coll Cardiol. 2008;51:1429-37.

35. Fan L, Chen L, Chen X, Fu F. A meta-analysis of stem cell mobilization by granulocyte colony-stimulating factor in the treatment of acute myocardial infarction. Cardiovasc Drugs Ther. 2008;22:45-54

36. Guo YH, He JG, Wu JL, Yang L, Zhang DS, Tan XY, et al. Hepatocyte growth factor and granulocyte colony-stimulating factor form a combined neovasculogenic therapy for ischemic cardiomyopathy. Cytotherapy. 2008;10:857-67.

37. Sanganalmath SK, Stein AB, Guo Y, Tiwari S, Hunt G, Vincent RJ, et al. The beneficial effects of postinfarct cytokine combination therapy are sustained during long-term follow-up. J Mol Cell Cardiol. 2009;47:528-35.

38. Okada H, Takemura G, Kosai K, Tsujimoto A, Esaki M, Takahashi $\mathrm{T}$, et al. Combined therapy with cardioprotective cytokine administration and antiapoptotic gene transfer in post- infarction heart failure. Am J Physiol Heart Circ Physiol. 2009;296:H616-626.

39. Huber BC, Fischer R, Brunner S, Groebner M, Rischpler C, Segeth A, et al. Comparison of parathyroid hormone and G-CSF treatment after myocardial infarction on perfusion and stem cell homing. Am J Physiol Heart Circ Physiol. 2010;298:H14661471.

40. Angeli FS, Amabile N, Shapiro M, Mirsky R, Bartlett L, Zhang Y, et al. Cytokine combination therapy with erythropoietin and granulocyte colony stimulating factor in a porcine model of acute myocardial infarction. Cardiovasc Drugs Ther. 2010;24:409-20.

41. Yeghiazarians Y, Khan M, Angeli FS, Zhang Y, Jahn S, Prasad M, et al. Cytokine combination therapy with long-acting erythropoietin and granulocyte colony stimulating factor improves cardiac function but is not superior than monotherapy in a mouse model of acute myocardial infarction. J Card Fail. 2010;16:669-78.

42. Fu ZH, Dong W, Gai LY, Wang F, Ding R, Chen YD. Effect of erythropoietin combined with granulocyte-colony stimulating factor in the treatment of acute myocardial infarction in rats. Nan Fang Yi Ke Da Xue Xue Bao. 2011;31:17-22.

43. Brunner S, Winogradow J, Huber BC, Zaruba MM, Fischer R, David R, et al. Erythropoietin administration after myocardial infarction in mice attenuates ischemic cardiomyopathy associated with enhanced homing of bone marrow-derived progenitor cells via the CXCR-4/SDF-1 axis. FASEB J. 2009;23:351-61.

44. Kang HJ, Kim MK, Kim MG, Choi DJ, Yoon JH, Park YB, et al. A multicenter, prospective, randomized, controlled trial evaluating the safety and efficacy of intracoronary cell infusion mobilized with granulocyte colony-stimulating factor and darbepoetin after acute myocardial infarction: study design and rationale of the 'MAGIC cell-5-combination cytokine trial'. Trials. 2011;12:33.

45. Lerner DL, Chapman Q, Green KG, Saffitz JE. Reversible downregulation of connexin43 expression in acute cardiac allograft rejection. J Heart Lung Transplant. 2001;20:93-7.

46. Cao JM, Fishbein MC, Han JB, Lai WW, Lai AC, Wu TJ, et al. Relationship between regional cardiac hyperinnervation and ventricular arrhythmia. Circulation. 2000;101:1960-9.

47. Kuhlmann MT, Kirchhof P, Klocke R, Hasib L, Stypmann J, Fabritz L, et al. G-CSF/SCF reduces inducible arrhythmias in the infarcted heart potentially via increased connexin 43 expression and arteriogenesis. J Exp Med. 2006;203:87-97.

48. Baldo MP, Davel AP, Nicoletti-Carvalho JE, Bordin S, Rossoni LV, Mill JG. Granulocyte colony-stimulating factor reduces mortality by suppressing ventricular arrhythmias in acute phase of myocardial infarction in rats. J Cardiovasc Pharmacol. 2008;52:375-80.

49. Kuwabara M, Kakinuma Y, Katare RG, Ando M, Yamasaki F, Doi $\mathrm{Y}$, et al. Granulocyte colony-stimulating factor activates Wnt signal to sustain gap junction function through recruitment of beta-catenin and cadherin. FEBS Lett. 2007;581:4821-30.

50. Lee TM, Chen CC, Chang NC. Granulocyte colony-stimulating factor increases sympathetic reinnervation and the arrhythmogenic response to programmed electrical stimulation after myocardial infarction in rats. Am J Physiol Heart Circ Physiol. 2009;297: H512-522. 